\title{
Rove beetles (Coleoptera: Staphylinidae) of a large pristine peat bog in Belarus Lake District
}

\author{
Gennadi G. SUSHKO \\ Vitebsk State University P. M. Masherov, Department of Ecology and Environmental Protection, Moskovski Ave. 33, \\ 21008 Vitebsk, Belarus; e-mail: gennadisu@tut.by
}

\begin{abstract}
Species composition and diversity of the rove beetles were studied in main habitats of a large pristine peat bog in Belarus Lake District (North-Western Belarus). Very specific staphylinid assemblages were found. They were characterized by not high species richness and diversity. In these uneven assemblages, a very small number of species: Drusilla canaliculata (Fabricius, 1787), Philonthus cognatus Stephens, 1832, Staphylinus erythropterus Linnaeus, 1758, Ischnosoma splendidus (Gravenhorst, 1806) dominated, while the majority of recorded species were rare. Unlike other inhabitants of the moss layer among the highly abundant species of rove beetles, peat bog specialists were not found. The highest diversity and evenness had the rove beetles assemblages in open spaces. On the other hand, the differences in these assemblages were not high.
\end{abstract}

Key words: staphylinid assemblages, diversity, natural peat bog, North-Western Belarus

\section{INTRODUCTION}

The Belarusian territory belongs to the Central-East European forest zone and mixed forest zone. The north-western part of Belarus is called Lake District. This region is characterized by a large area of peat bogs, the majority of which are preserved in the natural condition (185 400 ha). Bogs are peatlands with a high water table and low levels of nutrients (oligotrophic). They are always acidic and are dominated by Sphagnum mosses. Peat bogs are separate from other categories of wetlands, forming a distinctive type of wetland related to forest-tundra formations (Spitzer \& Danks 2006).

Peat bogs are very sensitive and endangered ecosystems in Central Europe. Belarus is one of the few countries in Central Europe with a large area of natural bogs (Bragg \& Lindsay 2003). The sizes of some bogs are very considerable: from several hectares up to several thousand hectares. Therefore Belarusian peat bogs are important for biodiversity studies of natural ecosystems.

The most abundant dwellers in bog habitats are insects especially those restricted to bogs (Spitzer \& Danks 2006, Spungis 2008, Sushko 2014). Diversity, composition and abundance of the insects that live in bogs help researchers interpret both the complex ecology and the long history of these habitats. It also gives useful insights for comparison from several scientific perspectives, suggesting the need for entomological study (Spitzer \& Danks 2006). Very little is known about the community structure and the diversity of insects of large natural ancient peat bogs, which are almost not preserved in Central Europe.

Study of Sphagnum cover dwellers has focused on the species composition of beetles, mainly ground beetles (Mossakowski 1971, Främbs et al. 2002, Mossakowski et al. 2003, Browarski 2005, Dapkus \& Tamutis 2008, Spungis 2008, Sushko 2014), with little information being known about staphilinids and their diversity (Mossakowski et al. 2003, Sushko 2016), which is widely distributed in terrestrial habitats, including peatlands, as well. Moreover, there have been only a few studies that have focused on the Sphagnum layer inhabitants diversity trends (Dapkus \& Tamutis 2008). 
The objective of the present study has been to assess the assemblages structure and diversity of rove beetles in large pristine peat bog.

\section{MATERIAL AND METHODS}

\section{Study sites}

The research was carried out between 2014 and 2016 on the peat bog "Moh" (4602 ha) one

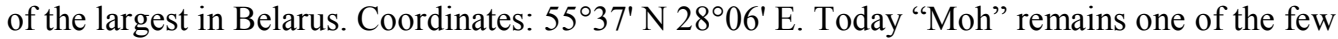
bogs in Central Europe preserved in natural conditions. The national status conservation of the peat bog is a hydrological reserve (Kozulin 2005).

Staphylinids were collected in main habitats such as lagg zone, pine bog, open bog and hummock-hollow complex. In each habitat 3 sites were selected. In each site we place 10 traps located approximately $10 \mathrm{~m}$ apart for a total of 30 traps per habitat.

Habitats characteristics: 1) lagg zone at the bog margin (plant community: Eriophorum vaginatum - Sphagnum angustifolium); 2) pine bog (plant community: Pinus sylvestris Eriophorum vaginatum - Ledum palustre + Calluna vulgaris $-S$. magellanicum $+S$. angustifolium); 3) open bog spaces (plant community: Eriophorum vaginatum - Ledum palustre + Calluna vulgaris - Sphagnum fuscum + S. magellanicum); 4) hummock of hummock-hollow complex (plant community: Eriophorum vaginatum - Oxycoccus palustris + Andromeda polifolia + Ledum palustre - Sphagnum magellanicum + S. angustifolium + S. fuscum).

\section{Research methods}

Staphylinid beetles were collected using pitfall traps from the end of April to the beginning of October. During this period, the rove beetles were extracted from the traps twice a month. Plastic cups with an opening diameter of $72 \mathrm{~mm}$ and a volume of $250 \mathrm{ml}$ were used as pitfall traps. A 4\% formaldehyde water solution was used as a fixation liquid. Each study site was divided into 10 cups located approximately $10 \mathrm{~m}$ apart for a total of 30 traps per habitat. Data of each habitat were summed up and mean values were calculated to obtain one dataset per habitat. To correct for large variances of specimen numbers within and among study sites the mean values for each habitats was natural log transformed.

Simpson (D) and Shannon indices $\left(\mathrm{H}^{\prime}\right)$ were used to calculate alpha diversity. Evenness was estimated using Pielou's index $(\mathrm{J})$. Beta diversity was evaluated through similarity among rove beetle assemblages, with the Bray-Curtis similarity index (Magurran 2004), which considers quantitative data (relative abundance). After calculation of the indices, the single linking method for hierarchical clustering was used to analyze the values obtained.

To estimate the total number of species, the bootstrap and Chao2 methods (Chao 1987) were used. Chao2 is a classic estimator based on single and double observations of occurrence of individual species in the samples (Chao 1987). Analyses were performed using Past ${ }^{\circledR}$ software (Hammer et al. 2001).

To analyze dominance the following classes were used: dominant (numbers $>5 \%$ ), subdominant $(2.01-5 \%)$, recedent $(1.01-2 \%)$ and subrecedent $(<1 \%)$ (Renkonen 1938).

\section{RESULTS}

\section{Species richness, abundance and dominance structure of rove beetle assemblages}

In total, 1491 individuals of 37 rove beetle species were recorded (Table 1). Staphylinid species richness and abundance significantly differed among the habitats (Kruskal-Wallis test, $\mathrm{p}$ $<0.05)$. 
Table 1. Composition (relative abundance, \%) of the rove beetle assemblages found in different peat bog habitats; abbreviations used: LZ - lagg zone; PB - pine bog, OBS - open bog spaces, HUM - hummocks.

\begin{tabular}{|c|c|c|c|c|c|}
\hline & \multirow[t]{2}{*}{ Species } & \multicolumn{4}{|c|}{ Habitats } \\
\hline & & $\mathrm{LZ}$ & PB & OBS & HUM \\
\hline 1 & Acidota crenata (Fabricius,1792) & 4.49 & 0.00 & 4.17 & 0.00 \\
\hline 2 & Anotylus rugosus (Fabricius, 1775) & 0.00 & 0.50 & 0.00 & 0.00 \\
\hline 3 & Bolitobius analis (Fabricius, 1787) & 1.12 & 0.00 & 0.00 & 0.00 \\
\hline 4 & Bolitobius formosus (Gravenhorst,1806) & 0.00 & 0.00 & 2.08 & 0.62 \\
\hline 5 & Bolitochara pulchra (Gravenhorst,1806) & 0.00 & 0.00 & 2.08 & 1.24 \\
\hline 6 & Drusilla canaliculata (Fabricius, 1787) & 78.65 & 79.90 & 31.25 & 74.53 \\
\hline 7 & Gymnusa brevicollis (Paykull,1800) & 0.00 & 1.01 & 0.00 & 3.11 \\
\hline 8 & Gyrohypnus atratus (Heer,1839) & 0.00 & 1.01 & 0.00 & 1.86 \\
\hline 9 & Ischnosoma bergrothi (Hellen,1925) & 2.25 & 0.00 & 4.17 & 0.00 \\
\hline 10 & Ischnosoma splendidus (Gravenhorst,1806) & 0.00 & 1.51 & 6.25 & 1.24 \\
\hline 11 & Lathrobium brunnipes (Fabricius,1792) & 0.00 & 0.50 & 0.00 & 0.00 \\
\hline 12 & Mycetoporus ruficornis Kraatz, 1857 & 0.00 & 0.50 & 0.00 & 0.00 \\
\hline 13 & Ochthephilum fracticorne (Paykull,1800) & 0.00 & 0.00 & 2.08 & 0.00 \\
\hline 14 & Ocypus fuscatus (Gravenhorst,1802) & 6.74 & 4.52 & 10.42 & 3.11 \\
\hline 15 & Ocypus nero (Faldermann,1835) & 0.00 & 0.00 & 2.08 & 0.00 \\
\hline 16 & Ontholestes murinus (Linnaeus, 1758) & 0.00 & 0.00 & 0.00 & 0.62 \\
\hline 17 & Othius myrmecophilus Kiesenwetter, 1843 & 0.00 & 1.51 & 0.00 & 0.00 \\
\hline 18 & Philonthus cognatus Stephens, 1832 & 0.00 & 1.01 & 0.00 & 1.86 \\
\hline 19 & Philonthus decorus (Gravenhorst, 1802) & 0.00 & 0.00 & 4.17 & 0.00 \\
\hline 20 & Philonthus nigrita (Gravenhorst,1806) & 0.00 & 2.01 & 0.00 & 0.00 \\
\hline 21 & Philonthus spinipes Sharp, 1874 & 1.12 & 0.00 & 2.08 & 0.62 \\
\hline 22 & Philonthus varius Gyllenhal,1810) & 0.00 & 0.00 & 2.08 & 1.24 \\
\hline 23 & Platydracus fulvipes (Scopoli,1763) & 0.00 & 0.50 & 4.17 & 0.00 \\
\hline 24 & Quedius fuliginosus (Gravenhorst, 1802) & 0.00 & 0.50 & 0.00 & 0.00 \\
\hline 25 & Sepedophilus pedicularis (Gravenhorst,1802) & 0.00 & 0.00 & 2.08 & 0.62 \\
\hline 26 & Sepedophilus testaceus (Fabricius, 1792) & 0.00 & 0.50 & 0.00 & 0.00 \\
\hline 27 & Staphylinus dimidiaticornis Gemminger, 1851 & 2.25 & 0.00 & 0.00 & 0.00 \\
\hline 28 & Staphylinus erythropterus Linnaeus, 1758 & 0.00 & 2.01 & 6.25 & 0.62 \\
\hline 29 & Stenus clavicornis (Scopoli,1763) & 0.00 & 0.00 & 2.08 & 0.00 \\
\hline 30 & Stenus lustrator Erichson, 1839 & 1.12 & 0.00 & 0.00 & 1.86 \\
\hline 31 & Stenus similis (Herbst,1874) & 0.00 & 1.01 & 4.17 & 0.00 \\
\hline 32 & Tachinus rufipes (Linnaeus, 1758) & 0.00 & 0.00 & 0.00 & 0.62 \\
\hline 33 & Tachyporus hypnorum (Fabricius, 1775) & 0.00 & 1.51 & 2.08 & 3.11 \\
\hline 34 & Tachyporus nitidulus (Fabricius, 1781) & 0.00 & 0.00 & 2.08 & 0.62 \\
\hline 35 & Xantholinus linearis (Olivier,1795) & 1.12 & 0.00 & 2.08 & 0.00 \\
\hline 36 & Xantholinus tricolor (Fabricius, 1787) & 1.12 & 0.00 & 0.00 & 2.48 \\
\hline 37 & Zyras collaris (Paykull, 1800) & 0.00 & 0.00 & 2.08 & 0.00 \\
\hline
\end{tabular}

Table 2. The main parameters of the rove beetle assemblages; abbreviations of habitats as above.

\begin{tabular}{lcccc}
\hline & \multicolumn{3}{c}{ Habitats } \\
\cline { 2 - 5 } \multicolumn{1}{c}{ Parameters } & LZ & PB & OBS & HUM \\
\hline Number of species & 10 & 17 & 21 & 18 \\
Chao 2 & 11.16 & 18.03 & 21.16 & 18.20 \\
Chao 2 st.dev. & 0.47 & 0.18 & 0.43 & 0.50 \\
Bootstrap & 11.75 & 17.5 & 22 & 19 \\
Bootstrap st.dev. & 0.52 & 0.45 & 0.19 & 1.1 \\
Number of species represented by 1-2 specimens & 7 & 10 & 17 & 10 \\
\% of species represented by 1-2 specimens & 70.0 & 59.0 & 80.0 & 56.0 \\
Number of species with abundance $>5 \%$ & 2 & 1 & 4 & 1 \\
\% of specimens of species with abundance $>5 \%$ & 85.4 & 80.0 & 54.17 & 74.53 \\
Shannon index (H') & 0.932 & 1.011 & 2.576 & 1.241 \\
Simpson index (D) & 0.626 & 0.642 & 0.130 & 0.560 \\
Pielou index (J) & 0.254 & 0.161 & 0.625 & 0.192 \\
\hline
\end{tabular}


The rove beetle assemblages per habitat included 10 to 21 species. The lowest number of species was recorded in the lagg (10), while the highest species richness was captured in the open bog (21). The expected number of species calculated on the basis of the Chao 2 and bootstrap was more than $85 \%$. The percentage contribution of recorded species of all assemblages to the estimated numbers indicates that the collected material is representative (Table 2). However, the list of recorded staphylinid species in the pine bog is incomplete, as the accumulation curve still shows an increasing trend (Fig. 1).

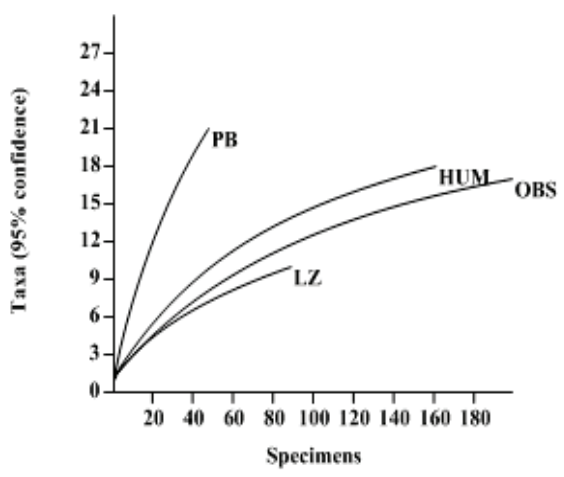

Fig. 1. Expected species richness based on the rarefaction curves for rove beetle assemblages of the peat bog habitats.

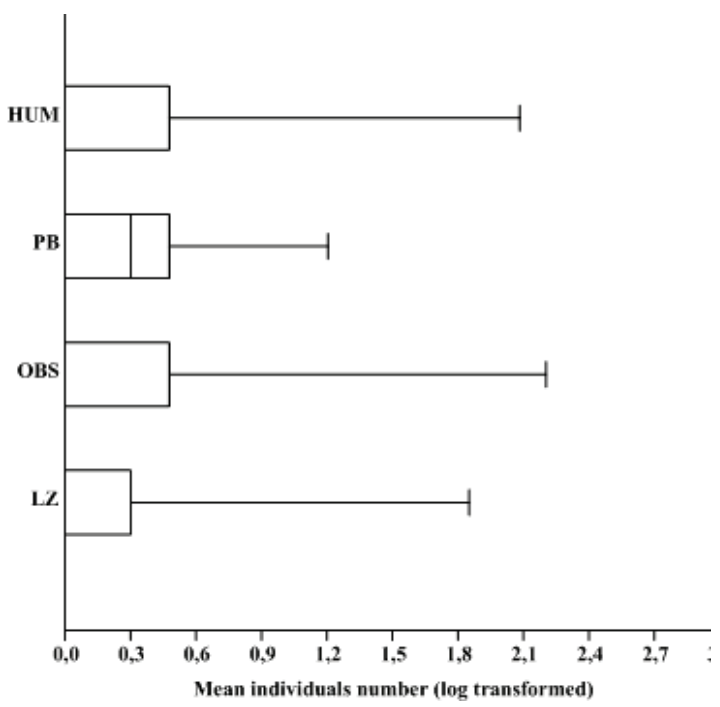

Fig. 2. Differences in total abundance (log-transformed) in rove beetle assemblages of the peat bog habitats.

Rove beetle abundances were highest in open bog and on the hummocks (Fig. 2). Drusilla canaliculata (31.25-79.9\%) was dominant and the most abundant species in all habitats. In addition, the dominants were Ocypus fuscatus (LZ and OBS), Ischnosoma splendidus (PB) and Staphylinus erythropterus (OBS), but their abundance was lower (Table 1). Subdominants included 3-4 species, except for open bog spaces rove beetle assemblages, where 17 subdominants were found. More than half of the species (56.0-80.0\%) caught in all habitats were represented by only 1-2 individuals. Only 5 species were recorded with abundance higher than $5 \%$ (Table 1$)$.

\section{Species diversity of rove beetle assemblages}

The highest diversity $\left(\mathrm{H}^{\prime}=2.576\right)$ was in the open bog sites, whereas the lowest Shannon index value was in the lagg zone $\left(\mathrm{H}^{\prime}=0.932\right)$. The Pielou evenness index $(\mathrm{J}=0.625)$ was also highest in the open bogs. In contrast, dominance peaked in lagg zone $(D=0.626)$ and pine bogs $(D=0.642)$, whereas the lowest average Simpson index was in open bogs $(D=0.130)$ (Table 2).

The cluster analysis showed highest similarities of staphylinid assemblages between open bog spaces (OBS) and hummocks (HUM). The assemblages of the pine bogs were least similar to those of the other habitats. On the other hand, the similarity among habitats as a whole, excluding pine bogs, was relatively high (Bray-Curtis coefficient of similarity >0.6) (Fig. 3). 


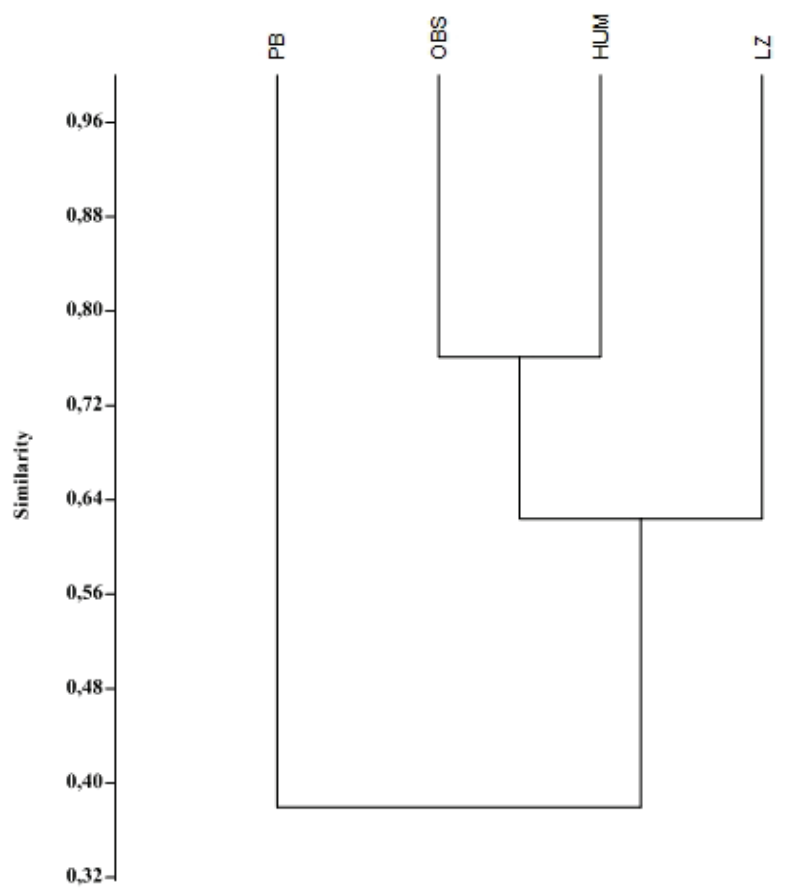

Fig. 3. Relative similarity of species composition of the rove beetle assemblages recorded in different peat bog habitats. The scale on the vertical axis is the Bray-Curtis coefficient of similarity (single linking method).

\section{DISCUSSION AND CONCLUSIONS}

Results of this study showed a low species richness of rove beetles in contrasting habitats of the bog. It is also found that a relatively small number of species showed high abundance, which is typical for other Sphagnum cover dwellers as well (Mossakowski 1971, Främbs et al. 2002, Mossakowski et al. 2003, Browarski 2005, Dapkus \& Tamutis 2008). Most recorded species occurred as singletons and doubletons. Staphylinid assemblages are dominated by a few abundant species, while the majority of species are scarce.

The most abundant species in all habitats was Drusilla canaliculata, while it is considered to belong to a large group of habitat unspecific species (Mossakowski et al. 2003). This very common eurytopic species occurs on different types of soils, under the low-growing plants, stones, fallen leaves, mosses and decaying plant debris (www.coleoptera.ksib.pl). Ocypus fuscatus is also among the dominants, but its abundance is lower. Ocypus fuscatus inhabits humid environments in forests and open areas (www.coleoptera.ksib.pl). Typhophilous species Gymnusa brevicornis was the only bog specialists, but its abundance was low. Other main inhabitants of the moss layer are ground beetles and ants, but, in contrast, among them stenobiont species of peat bogs dominated (Sushko 2014).

The open habitats had the highest staphylinid species richness and abundance in comparison with the flooded boundary lagg zone and pine bogs. However, the similarity of the rove beetle assemblages was relatively high.

Thus, in a large natural peat bog, very specific staphylinid assemblages were found. They were characterized by low species richness, diversity and evenness. The highest diversity in open bog spaces was recorded. The differences in rove beetle assemblages were relatively not high. 


\section{REFERENCES}

Bragg O. \& Lindsay R. (eds) 2003. Strategy and Action Plan for Mire and Peatland Conservation in Central Europe. Central European Peatland Project (CEPP). Wetlands International Publication 18, Wageningen, 93 pp.

BROWARSKI B. 2005. The carabid fauna of "Torfiaki" raised peat-bog (north-eastern Poland). Pp. 137-145. In: SkŁodowski J., Huruk S., BarŠEvskis A., TARAsiuk S., Protection of Coleoptera in the Baltic Sea Region, Warsaw Agricultural University Press, Warsaw, 239 pp.

CHAO A. 1987. Estimating the population size for capture-recapture data with unequal catchability. Biometrics 43: 783-791

COLEOPTERA POLONIAE. Available at http: //www.coleoptera.ksib.pl (10 Dec 2017)

DAPKUS D. \& TAMUTIS V. 2008. Assemblages of beetles (Coleoptera) in a peat bog and surrounding pine forest. Baltic Journal of Coleopterology 8 (1): 31-40

FrämbS H., DORMANN W. \& MOSSAKOWSKi D. 2002. Spatial distribution of carabid beetles on Zehlau bog. Baltic Journal of Coleopterology 2 (1): 7-15

HAMmer Ø., HARPe D. A. T. \& RYAN R. D. 2001. PAST: Paleontological Statistics Software Package for Education and Data Analysis. Palaeontologia Electrónica 4 (1): 9. Available at http://palaeo-electronica.org (1 Dec 2017)

KozUlin A. V. (eds). 2005. Treasures of Belarusian Nature. Areas of international significance for conservation of biological diversity. Minsk: 215 pp. [In Russian and in English]

MagurRan A. E. 2004. Measuring biological diversity. Oxford: Blackwell Publishing, 215 pp.

MOSSAKOWSKI D. 1971. Ökologische Untersuchungen an epigaischen Coleoptern atlantischen Moor und Heidenstandorte. Zeitschrift Wissenschaft Zoologie 18 (2): 231-316.

Mossakowski D., Frambs H. \& LAKOMY W. 2003. The Carabid and Staphylinid fauna of raised bogs. A comparison of Northwest Germany and the Baltic region. Baltic Journal of Coleopterology 3 (2): 137-144

RENKONEN O. 1938. Statisch-ökologische Untersuchungen über die terrestiche Käferwelt der finischen Bruchmoore. Annales Zoologici. Societas Zoologica-Botanica Fennici. Vanamo 6: 1-226.

SPITZER K. \& DANKS H. V. 2006. Insect biodiversity of boreal peat bogs. Annual Review of Entomology 51: 137-161. SPUNGIS V. 2008. Fauna and ecology of terrestrial invertebrates in raised bog in Latvia. Riga: Latvias Entomology Bedriba, 80 pp.

SushKo G. 2014. Spatial distribution of epigeic beetles (Insecta, Coleoptera) in the "Yelnia" peat bog. Baltic Journal of Coleopterology 14 (2): 151-161

SuSHKO G. 2016. Species composition and zoogeography of the rove beetles (Coleoptera: Staphylinidae) of raised bogs of Belarus. North-Western Journal of Zoology 12 (2): 47-63.

\section{STRESZCZENIE}

\section{[Kusakowate (Coleoptera: Staphylinidae) naturalnych torfowisk Pojezierza Białoruskiego]}

Zbadano skład gatunkowy i różnorodność gatunkową w zgrupowaniach kusakowatych w czterech środowiskach rozległego dziewiczego bagna „Moh” (4602 ha) na Pojezierzu Białoruskim (Północno-Zachodnia Białoruś). Badania przeprowadzono w latach 2014-2016. Ogółem stwierdzono 37 gatunków kusakowatych, tworzących bardzo specyficzne zgrupowania, które charakteryzują się niewysokim bogactwem i umiarkowaną różnorodnością. Największe zróżnicowanie gatunkowe (indeks Shannona $\mathrm{H}^{\prime}=2.576$ ) wykazują otwarte tereny bagienne (OBS), najmniejsze $\left(\mathrm{H}^{\prime}=0.932\right)$ stwierdzono w strefie okrajkowej $(\mathrm{LZ})$. W tych nierównych zgrupowaniach dominuje niewielka liczba gatunków, podczas gdy większość jest rzadka. Drusilla canaliculata (31.25-79.9\%) jest dominantem i najliczniejszym gatunkiem we wszystkich środowiskach.

Analiza klastryczna pokazuje najwyższe podobieństwo w zgrupowaniach kusakowatych pomiędzy miejscami otwartej przestrzeni bagiennej (OBS) a wrzosowiskiem o budowie kępkowej (HUM). Najmniej podobne do innych środowisk były zgrupowania ze strefy okrajkowej (LZ). Z drugiej strony podobieństwo pomiędzy zgrupowaniami wszystkich badanych środowisk, wyłączając strefę okrajkową było relatywnie wysokie (indeks BrayCurtisa >0.6). W odróżnieniu od innych bezkręgowców zasiedlających warstwę mszysta, wśród najbardziej licznych gatunków kusakowatych nie stwierdzono specjalisty torfowiskowego. Pałkolubny gatunek Gymnusa brevicornis okazał się jedynym torfowiskowym specjalista, ale jego liczebność była niska. 